\title{
Fermentation characteristics in stirred-tank reactor of exopolysaccharides with hypolipidemic activity produced by Pleurotus geesteranus $5^{\#}$
}

\author{
MAO DUOBIN ${ }^{1}$, MA YUPING ${ }^{2}$, GENG LUJING ${ }^{1}$, ZHAO AIJING ${ }^{3}$, \\ ZHENG JIANQIANG ${ }^{1}$ and XU CHUNPING ${ }^{{ }^{*}}$ \\ ${ }^{1}$ College of Food and Biological Engineering, Zhengzhou University of Light Industry, 450002, Henan, China \\ ${ }^{2}$ China Tobacco Henan Industrial Co. Ltd, Zhengzhou, 450016, Henan, China \\ ${ }^{3}$ College of Life Sciences, Henan Normal University, 450002, Henan, China
}

Manuscript received on February 4, 2013; accepted for publication on June 16, 2013

\begin{abstract}
In this study, the hypolipidemic effect of exopolysaccharides (EPS) from Pleurotus geesteranus $5^{\#}$ fermenting liquor by the optimal culture conditions in a 5-L stirred-tank reactor was investigated. The hypolipidemic effect of the polysaccharide, investigated in streptozotocin induced diabetic mice, decreased plasma glucose, total cholesterol and triacylglycerol concentrations by $17.1 \%, 18.8 \%$ and $12.0 \%$, respectively. The results of the present investigation strongly demonstrate the potential of this polysaccharide to prevent hyperglycemia in the experimental animals. Under optimal culture conditions, the maximum concentrations of mycelial and EPS were $22.63 \mathrm{~g} / \mathrm{L}$ after $7 \mathrm{~d}$ cultivation and $11.09 \mathrm{~g} / \mathrm{L}$ after $10 \mathrm{~d}$, respectively. Furthermore, the morphological parameters (i.e. mean diameter, circularity, roughness and compactness) of the pellets and the broth viscosity were characterized. It was proved that compactness of the pellet morphology $\left(\mathrm{R}^{2}=0.963, \mathrm{p}<0.01\right)$ was significantly and positively determined with mycelial biomass. Moreover, mean diameter $\left(\mathrm{R}^{2}=93.3, \mathrm{p}<0.01\right)$ and broth viscosity $\left(\mathrm{R}^{2}=0.950, \mathrm{p}<0.01\right)$ were significantly and positively determined with EPS content.
\end{abstract}

Key words: exopolysaccharides, Pleurotus geesteranus, fermentation, hypolipidemic effect, morphology.

\section{INTRODUCTION}

Modern pharmacological studies have shown that polysaccharide from medical fungi with a wide variety of medicinal applications. In particular, hypolipidemic and hpyerglycemic activities of polysaccharide from many fungi have been documented, which are hotspots of research on functional factors of health food and medicines with high efficiency and low toxicity (Hwang et al. 2005, Hwang and Yun 2010). Recently,

Correspondence to: Chun-Ping Xu

E-mail: c.p.xu@zzuli.edu.cn submerged fermentation has received great interest as a promising technique for efficient production of exopolysaccharides (EPS) with the hypolipidemic effect extracted from fermentation broth of medicinal fungi (Song et al. 1998, Yang et al. 2006).

Filamentous fungal morphology is an important parameter which influences the physical properties in submerged fermentation. The rheological behavior was influenced by the morphology and biomass concentration (Riscaldati et al. 2000, Sinha et al. 2001). The broth rheology, in turn, determines the transport phenomena in bioreactors that is the 
key to improved yield of the desired product (Cerri and Badino 2012, Yesilada et al. 1998).

Pleurotus geesteranus is a species that is that is getting the popularity lately because of its very pleasant flavour, richness of dietary fibre and high quality of proteins. The extract of $P$. geesteranus has anticancer and antioxidant activities (Wang et al. 2011, Zhang et al. 2011). However, to our knowledge, there is no report about the hypolipidemic effect of $P$. geesteranus polysaccharide.

The aim of the present work was to evaluate the hypolipidemic activity of $P$. geesteranus $5^{\#}$ EPS in male Kunming mice. Furthermore, EPS production kinetics by $P$. geesteranus $5^{\#}$ was investigated in a stirred-tank reactor, and the possible relationship between physical parameters (i.e. mycelial morphology and broth viscosity) and metabolite production (biomass and EPS) during fermentation was revealed.

\section{MATERIALS AND METHODS}

\section{Microorganism AND GROWTH CONDITIONS}

P. geesteranus $5^{\#}$ was obtained from the Henan Province Microbiological Culture Collection Center (HPMCC no. 197787-5\#) and was used throughout this study. Stock cultures were maintained on potato dextrose agar (PDA) slants. The seed culture was grown in a $250 \mathrm{~mL}$ flask containing $50 \mathrm{~mL}$ of GP medium $(0.3 \%$ peptone, $3 \%$ glucose $)$ at $26{ }^{\circ} \mathrm{C}$ on a rotary shaker incubator ( $150 \mathrm{rpm}$ ) for $4 \mathrm{~d}$. Inoculum was prepared by the method as the same as previous works (He et al. 2013).

ANIMAL EXPERIMENTS AND INDUCTION OF DIABETES

5-week old male Kunming mice was obtained from Henan Experimental Animal Center (Zhengzhou, China) were housed individual in stainless steel cages and acclimatized with free access to food and water for at least 1 week in an air conditioned room ( $23 \pm 2{ }^{\circ} \mathrm{C}$ with $55 \pm 5 \%$ humidity) and a $12 \mathrm{~h}$ cycle of light and dark. The mice were fed with a commercial pellet diet (Henan Experimental Animal Center) throughout the experimental period.

After one week of acclimatization in the growth room, they were brought into the growth room. Diabetes was induced by intramuscular injection of streptozotocin (Sigma Chemical Co., Louis, MO) dissolved in $0.1 \mathrm{M}$ sodium citrate buffer $(\mathrm{pH} 4.5)$ at a dose of $50 \mathrm{mg} / \mathrm{kg}$ body weight (Hwang et al. 2008). Two days after injection of diabetogenic agent (streptozotocin), fasting blood glucose was determined and the mice with more than blood glucose $>300 \mathrm{mg} / \mathrm{dL}$ were included in the group of diabetics. At the end of oral administration, the animals were fasted for $9 \mathrm{~h}$ and then sacrificed. All procedures were conducted in accordance with the "Guide for the Care and Use of Laboratory Animals" approved by Zhengzhou University of Light Industry.

ANIMAL EXPERIMENTAL DESIGN AND ANALYTICAL

MEASUREMENTS

All the animals were randomly divided into three groups with eight animals in each group (Table I): normal group, normal mice received $0.9 \% \mathrm{NaCl}$ solution; control group, STZ-induced diabetic mice treated with $0.9 \% \mathrm{NaCl}$ solution; diabetic EPStreated group, diabetic mice high-treated with $P$. geesteranus $5^{\#}$ EPS from a stirred-tank reactor at the level of $200 \mathrm{mg} / \mathrm{kg}$ body weight using an oral daily dose for three weeks. On the basis of our preliminary test result (doses of 100 and $200 \mathrm{mg} / \mathrm{kg}$ ) and other experimental designs by several investigators who used natural sources for diabetic therapy (normal dose ranges: 100-300 mg/kg), $200 \mathrm{mg} / \mathrm{kg}$ was chosen as a suitable dose for this experiment (Hwang et al. 2005, Hwang and Yun, 2010).

The fasting blood samples of the experimental animals were collected in heparinized tubes and plasma was separated by centrifugation at $1,100 \mathrm{~g}$ for $10 \mathrm{~min}$. Each organ was isolated and the weights were measured after washing with $0.9 \% \mathrm{NaCl}$. The 
TABLE I

Experimental groups for dose-dependent hypolipidemic activity of $P$. geesteranus $5^{\#}$ EPS.

\begin{tabular}{|c|c|}
\hline Group & Oral administration \\
\hline Normal $^{\mathrm{a}}$ & None \\
\hline Control $^{\mathrm{b}}$ & $0.9 \% \mathrm{NaCl}$ \\
\hline EPS $^{\mathrm{b}}$ & $200 \mathrm{mg} / \mathrm{kg} \bullet \mathrm{d}$ P. geesteranus $5^{\#}$ EPS \\
\hline
\end{tabular}

${ }^{\mathrm{a}}$ Group of 8 normal mice. ${ }^{\mathrm{b}}$ Diabetic mice induced by streptozotocin $(50 \mathrm{mg} / \mathrm{kg}$ body weight) for 8 mice. The mice were administrated orally with either saline (control) or EPS produced from the submerged mycelial culture of $P$. geesteranus $5^{\#}$ at $200 \mathrm{mg} / \mathrm{kg}$ body weight daily for 3 weeks.

plasma glucose level was measured using glucose oxidase kit (Biosino Bio-technology And Science Inc, Beijing, China). Total cholesterol, triglyceride levels were measured using a CHOD-PAP method (Biosino Bio-technology And Science Inc, Beijing, China) (Henry, 1974). HDL cholesterol was evaluated by enzymatic test kits (Biosino Bio-technology And Science Inc, Beijing, China) using PEG-modified enzymes (Okada et al. 2001). LDL cholesterol and atherogenic index (AI) were calculated by the following equations:

LDL cholesterol $=$ total cholesterol - HDL cholesterol - (triglyceride/5)

$\mathrm{AI}=($ total cholesterol $-\mathrm{HDL}$ cholesterol $) / \mathrm{HDL}$ cholesterol

HTR $=$ HDL cholesterol/total cholesterol

\section{FERMENTATIONS IN BIOREACTORS}

$4 \%(\mathrm{v} / \mathrm{v})$ of mycelial suspensions was carried out in a 5-L stirred-bank (Infors, Switzerland). Unless otherwise specified, fermentations were performed under the following optimized conditions: 60.0 g maltose, $5.0 \mathrm{~g}$ tryptone, $1 \mathrm{mM} \mathrm{NaCl}, 5 \mathrm{mM}$ $\mathrm{KH}_{2} \mathrm{PO}_{4}$, and initial pH 6.0 at $28{ }^{\circ} \mathrm{C}$, agitation speed $150 \mathrm{rpm}$, aeration rate $2 \mathrm{vvm}$, working volume $3 \mathrm{~L}$, cultivation time 11d. Samples were taken aseptically at intervals for analyses (He et al. 2013). All experiments were performed in triplicate to ensure the trends observed were reproducible.
DETERMINATION OF MYCELIAL DRY WEIGHT AND EPS PRODUCTION

The methods to determine mycelial dry weight and EPS concentration were the same as previous works (Bae et al. 2000). The EPS produced from the stirredtank reactor was used for the animal experiments.

\section{MEASUREMENTS OF THE Viscosity AND MORPHOLOGY}

The viscosity measurements were performed on samples collected from bioreactor at regular intervals using a Broolfield programmable LVD-VII + digital viscometer fitted with a disc-spindle impeller and a small sample adapter. For a given sample liquid, the shear rate on the impeller is proportional to the impeller speed. Apparent viscosity was obtained from the meter reading; shear rate $\gamma$ was calculated from its relationship with an impeller speed. For most fermentation liquids, the shear stress $\tau$ is related to the shear rate $\gamma$ by the simple power law model of Ostwald-de Waele,

$$
\tau=K \cdot \gamma^{n}=\eta_{a} \cdot \gamma(1)
$$

where $K$ is the consistency index, and $n$ is the flow behavior index. $K$ and $\mathrm{n}$ were determined from logarithmic plots of $\eta_{a}$ versus $\gamma$ (Sinha et al. 2001).

The morphological properties of the samples collected were evaluated using an image analyzer (DT2000 System, China) with software linked to a light microscope (Nikon, Japan) through a CCD camera. Samples were fixed with an equal volume of fixative (13 $\mathrm{ml}$ of $40 \%$ formaldehyde, $5 \mathrm{ml}$ glacial acetic acid, $200 \mathrm{~mL}$ of $50 \%$ ethanol). An aliquot $(0.1 \mathrm{~mL})$ of each fixed sample was transferred to a slide, air dried, and then stained with methylene blue ( $0.3 \mathrm{~g}$ of methylene blue, 30 $\mathrm{ml}$ of $95 \%$ ethanol in $100 \mathrm{~mL}$ water). For each sample, the morphology of pellet was characterized by measuring the area and perimeter of the pellet core and the maximum diameter of the pellet. Normally, a 40-fold magnification was used. The morphology of the pellets was characterized by their mean diameter, circularity, roughness and 
compactness. The circularity was estimated as the ratio of the Fieret's minimum diameter to the Fieret's maximum diameter of the pellets or aggregates. The compactness was estimated as the ratio of the projected area of the hyphae in a clump to the projected convex area of that clump, the latter being the area after filling internal voids and concavities in the clump's external perimeter. In addition, the roughness ( $\mathrm{R})$ was measured using the following equation: $\mathrm{R}=$ (pellet/aggregate perimeter) $2 /(4 \pi \times$ pellet area) (Park et al. 2001).

\section{STATISTICAL ANALYSIS}

Data were expressed as mean \pm S.D. Group means were compared by one-way analysis of variance (ANOVA) test using the Statistical Package of the Social Science (SPSS) version 11.0 (SPSS Inc., Chicago, IL, USA). Group means were considered to be significantly different at $\mathrm{P}<0.05$. Using the Pearson coefficient analysis was used to analyze the coefficient of determination $\left(R^{2}\right)$ and evaluate the relationship between EPS content and mean diameter, circularity, and roughness.

\section{RESULTS AND DISCUSSION}

\section{HYPOLIPIDEMIC EFFECT OF EPS}

In this study, the hypolipidemic effects of EPS from $P$. geesteranus $5^{\#}$ in streptozotocin-induced diabetic mice were evaluated with respect to that of the saline administered control group. The final organ weights of the experimental animals are showed in Table II. By the end of the experiment in week 3 , the weight of liver decreased significantly by administration of EPS. However, the EPS treatment had no influence on kidney, spleen and pancreas weight, compared to the Normal and Control groups. Moreover, oral administration of the EPS caused no changes in gross behavior and none of the animals died, which indicated that there were no harmful effects in the mice cause by oral administration of the EPS of $P$. geesteranus $5^{\#}$. The effect of EPS on the blood glucose level in streptozotocin-induced diabetic mice over 3 week period is depicted in Table III. The blood glucose level dropped $17.1 \%$ significantly when the EPS was administered. It has been reported that the streptozotocin treatment caused degranulation or reduction of insulin secretion by the pancreas was through selective destruction of $\beta$-cells in the pancreatic islets (Benwahhoud et al. 2001). It seems that EPS repair the damage of the pancreatic $\beta$-cells that initially survived streptozotocin toxicity or behaving as an insulin-like factor to promote insulin synthesis and thus lowered the level of plasma glucose (Yang et al. 2006).

TABLE II

Effect of $P$. geesteranus $5^{\#}$ EPS on the various organs in streptozotocin-induced diabetic mice for 3 weeks.

\begin{tabular}{|c|c|c|c|c|}
\hline Group $^{1}$ & $\begin{array}{c}\text { Liver } \\
(\mathrm{g} / 100 \mathrm{~g} \\
\mathrm{BW})\end{array}$ & $\begin{array}{c}\text { Kidney } \\
(\mathrm{g} / 100 \mathrm{~g} \\
\text { BW) }\end{array}$ & $\begin{array}{c}\text { Spleen } \\
(\mathrm{g} / 100 \mathrm{~g} \\
\mathrm{BW})\end{array}$ & $\begin{array}{c}\text { Pancreas } \\
(\mathrm{g} / 100 \mathrm{~g} \\
\mathrm{BW})\end{array}$ \\
\hline Normal & $\begin{array}{c}4.16 \pm \\
0.05^{\mathrm{a}}\end{array}$ & $\begin{array}{c}1.31 \pm \\
0.15^{\mathrm{a}}\end{array}$ & $\begin{array}{l}0.30 \pm \\
0.08^{\mathrm{NS}}\end{array}$ & $\begin{array}{l}0.35 \pm \\
0.07^{\mathrm{NS}}\end{array}$ \\
\hline Control & $\begin{array}{c}5.34 \pm \\
0.08^{\mathrm{c}}\end{array}$ & $\begin{array}{l}1.75 \pm \\
0.11^{\mathrm{b}}\end{array}$ & $\begin{array}{c}0.29 \pm \\
0.04\end{array}$ & $\begin{array}{c}0.31 \pm \\
0.09\end{array}$ \\
\hline EPS & $\begin{array}{c}4.79 \pm \\
0.09^{\mathrm{b}}\end{array}$ & $\begin{array}{l}1.54 \pm \\
0.10^{\mathrm{ab}}\end{array}$ & $\begin{array}{c}0.28 \pm \\
0.07\end{array}$ & $\begin{array}{c}0.42 \pm \\
0.05\end{array}$ \\
\hline
\end{tabular}

${ }^{1}$ See Table I. Each value is the mean $\pm \mathrm{SE}(\mathrm{n}=8)$. ${ }^{\mathrm{a}, \mathrm{b}, \mathrm{c}}$ Values with different superscript letters in the same column significantly different among the groups at $\mathrm{p}<0.05$.

The present investigation demonstrated that a maximum reduction of total cholesterol and triacylglycerol of $18.8 \%$ and $12.0 \%$ respectively, was obtained at a dose of $200 \mathrm{mg} / \mathrm{kg}$ body weight (Table III). The decrease in total cholesterol and triacylglycerol level in the diabetic mice by EPS reinforces its hypolipidemic potential. In general, the high plasma level of triacylglycerol and total cholesterol observed in diabetic animals may be due to impaired liver function caused by the damage done by streptozotocin (as showed the increased weight of the liver after mice were induced by streptozotocin in Table II), which acts either directly or indirectly by enhancing the plasma glucose level 
TABLE III

Effect of $P$. geesteranus $5^{\#}$ EPS on plasma glucose, total cholesterol, triglyceride levels, plasma HDL cholesterol, LDL cholesterol, atherogenic index in streptozotocin-induced diabetic mice for 3 weeks.

\begin{tabular}{|c|c|c|c|}
\hline Group $^{1}$ & Normal & Control & EPS \\
\hline \multicolumn{4}{|c|}{ plasma glucose, total cholesterol, and triglyceride levels } \\
\hline Glucose (mmol/L) & $5.97 \pm 1.17^{\mathrm{a}}$ & $36.90 \pm 0.99^{\mathrm{c}}$ & $30.58 \pm 2.80^{\mathrm{b}}$ \\
\hline Total cholesterol (mmol/L) & $2.82 \pm 0.26^{\mathrm{a}}$ & $4.64 \pm 0.13^{\mathrm{c}}$ & $3.77 \pm 0.40^{\mathrm{b}}$ \\
\hline Triglyceride $(\mathrm{mmol} / \mathrm{L})$ & $1.23 \pm 0.10^{\mathrm{a}}$ & $1.67 \pm 0.06^{\mathrm{c}}$ & $1.47 \pm 0.06^{\mathrm{b}}$ \\
\hline \multicolumn{4}{|c|}{ plasma HDL cholesterol, LDL cholesterol, and atherogenic index } \\
\hline HDL cholesterol (mmol/L) & $1.36 \pm 0.06^{\mathrm{c}}$ & $0.77 \pm 0.08^{\mathrm{a}}$ & $1.04 \pm 0.10^{\mathrm{b}}$ \\
\hline LDL cholesterol $^{2}(\mathrm{mmol} / \mathrm{L})$ & $1.39 \pm 0.07^{\mathrm{a}}$ & $3.54 \pm 0.04^{\mathrm{c}}$ & $2.60 \pm 0.29^{\mathrm{b}}$ \\
\hline Atherogetic Index ${ }^{3}$ & $1.20 \pm 0.10^{\mathrm{a}}$ & $5.06 \pm 0.50^{\mathrm{c}}$ & $2.78 \pm 0.07^{\mathrm{b}}$ \\
\hline
\end{tabular}

${ }^{1}$ See Table I. ${ }^{2}$ Total cholesterol - HDL cholesterol - (Triglyceride/5). ${ }^{3}$ (Total cholesterol - HDL cholesterol)/ HDL cholesterol. Each value is mean \pm SE for 8 mice. ${ }^{a, b, c}$ Values with different superscript letters in the same column significantly different among the groups at $\mathrm{p}<0.05$.

(Van Horn 1996). This hypolipidemic activity might act through the stimulation of pancreas cells, which are able to enhance insulin secretion by binding to sulfonylureas receptors on the $\beta$-cell (Bolkenta et al. 2000, Hwang et al. 2008).

Table III also shows the effect of EPS on the LDL cholesterol, HDL cholesterol and atherogenic index in streptozotocin-induced diabetic mice. In comparison with the control group, the HDL cholesterol level, LDL cholesterol and atherogenic index were substantially increased by the oral administration of the EPS of $P$. geesteranus $5^{\#}$ by $35.1 \%, 26.6 \%$ and $45.1 \%$, respectively. These results suggest that $P$. geesteranus $5^{\#}$ EPS might behavior as a modulator to correct the liver function by promoting insulin synthesis due to its lowering action on apolipoprotein mRNA or its enhancing action on HDL receptor activity, thereby reducing the blood glucose level. In turn, this reduced the level of triacylglycerol and total cholesterol in blood plasma of diabetic animals. In light of the present knowledge, a substantial reduction of LDL and total cholesterol in plasma can be achieved by reduced production of total cholesterol (Gray and Flatt, 1998). Therefore, in the current investigation, the reduced on the LDL cholesterol, HDL cholesterol and atherogenic index under the influence of the EPS was consistent with the above supposition.

\section{Cultivation In StiRRed TANK REACTOR}

The typical time courses of mycelial growth and the yield of EPS in a 5-L stirred-tank bioreactor under optimal culture conditions for the yield of EPS are shown in Figure 1. The maximum mycelial yield was obtained $22.63 \mathrm{~g} / \mathrm{L}$ after $7 \mathrm{~d}$ (Figure 1A), and the yield of EPS indicated $11.09 \mathrm{mg} / \mathrm{L}$ after $10 \mathrm{~d}$ of fermentation (Figure 1B). As expected, the concentration of residual sugars decreased as the fermentation progressed with corresponding increases in biomass and EPS production (Figure 1C). However, no drastic change in $\mathrm{pH}$ value was recorded during course of fermentation (Figure 1D).

CHARACTERIZATION OF BROTH VISCOSITY AND MYCELIAL

\section{MORPHOLOGY}

The apparent viscosity of the whole broth according to the fermentation period is depicted in Figure 2A. After day 1, the viscosity of the fermentation broth at $300 \mathrm{rpm}$ increased rapidly as the cells entered their exponential growth. This continued up to day $8(375.0 \mathrm{mPa} \bullet \mathrm{S})$, which microorganisms entered their stationary phase and the viscosity 


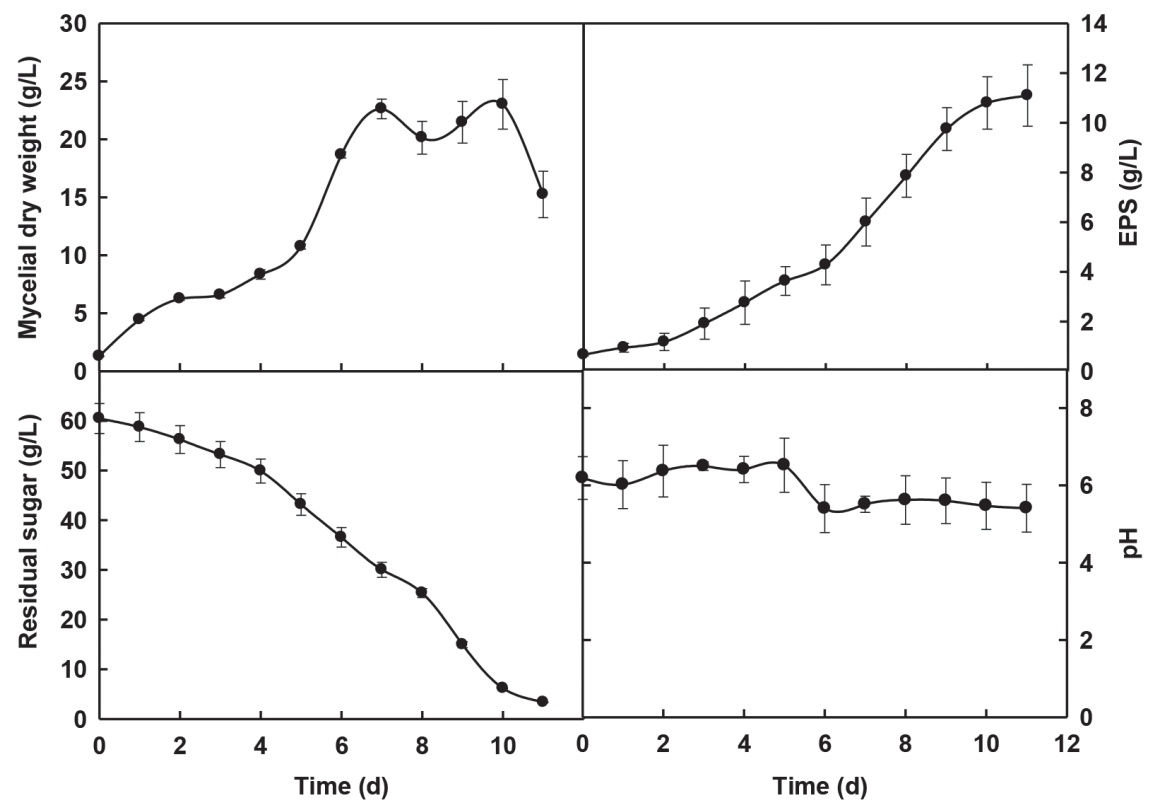

Fig. 1 - Time profiles of mycelial biomass (A), EPS (B), residual sugar (C), and pH (D) in submerged culture of $P$. geesteranus $5^{\#}$ in a stirred-tank fermenter.
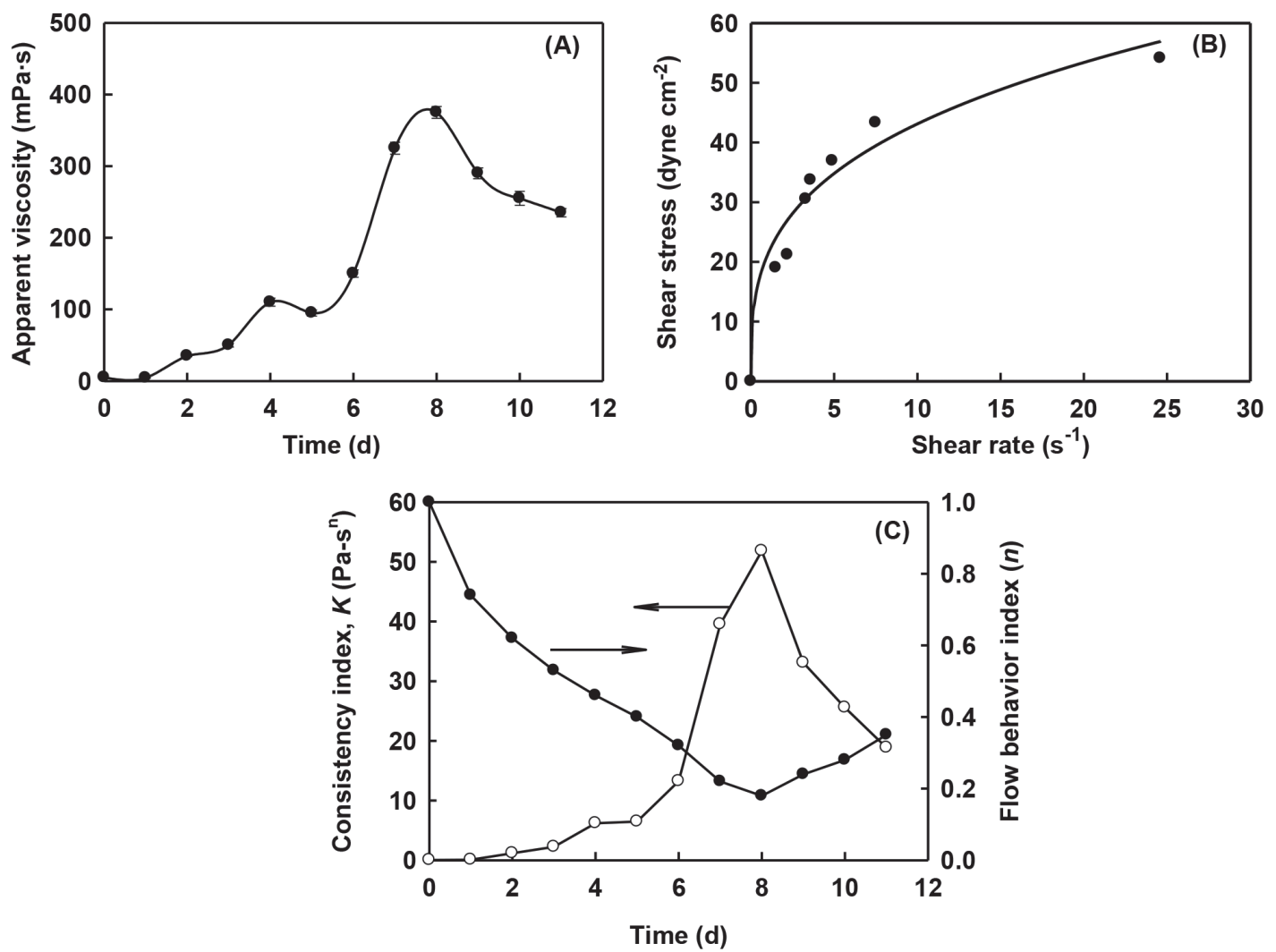

Fig. 2 - Rheological properties of P. geesteranus $5^{\#}$ mycelial broth over the fermentation period: apparent viscosity of whole fermentation broth (A); rheographs for fermentation broth (shear stress vs. shear rate plots) (B), and the variation in consistency index $(\mathrm{K})$ and flow behavior index (n) of whole fermentation broth $(\mathbf{C})$. 
of the broth, which was proportional to the cell concentration, declined accordingly. As in many fungal fermentations, the fermentation broths displayed almost a pseudoplastic behavior with the flow behavior index $n<1$, indicating a power law relationship (Figure 2B and 2C). Figure 2C shows the variation in consistency index $(K)$ and flow behaviour index $(n)$ of the fermentation broth. The consistency index $(K)$ continued to rise from the early fermentation period; however, a significant decline was observed at the end of fermentation. The flow behavior index, $n$, continued to decrease until day 8 , and thereafter a significant increase towards the end of fermentation was observed, which was similar to the trend reported for Paecilomyces japonica fermentation (Sinha et al. 2001).

Figure 3 shows the typical morphological changes during the entire fermentation period (0-11d). The cells were observed to form mainly pellets during the entire culture period. The pellet diameter increased rapidly and the outer hairy regions of the pellets became fluffier. However, as the fermentation processed, especially the day 11 , the outer hairy region of the pellets was shaved off. Figure 4 shows the mean diameter (A), circularity (B), roughness (C), and compactness (D) of the pellets during cultivation of $P$. geesteranus $5^{\#}$. The mean diameter and compactness of the pellets increased during the first 0 and 5 days of fermentation, respectively, and then vibrated, but no drastic changes in circularity and roughness were revealed during course of fermentation. Further investigation of the EPS accumulation in the mycelial pellets during the first $5 \mathrm{~d}$ of the fermentation period revealed that compactness of the pellet morphology $\left(R^{2}=0.963, \quad \mathrm{p}<0.01\right) \quad$ was significantly positively determined with mycelial biomass, moreover, mean diameter $\left(R^{2}=93.3, \mathrm{p}<0.01\right)$ and broth viscosity $\left(R^{2}=0.950, \mathrm{p}<0.01\right) \quad$ were significantly positively determined with EPS content. These results clearly seen that the viscosity and mycelial morphological changes were coincidental with fungal biomass and EPS production, respectively. Park et al. (2002) also reported the compactness of pelleted form of Cordyceps militaris was related to EPS production. It is interesting to note that the relationships between the physical parameters and metabolic products become unclear at the later stage of culture (after $5 \mathrm{~d}$ ). This indicated that the metabolic process become more complicated during and after exponential phase of fermentation.

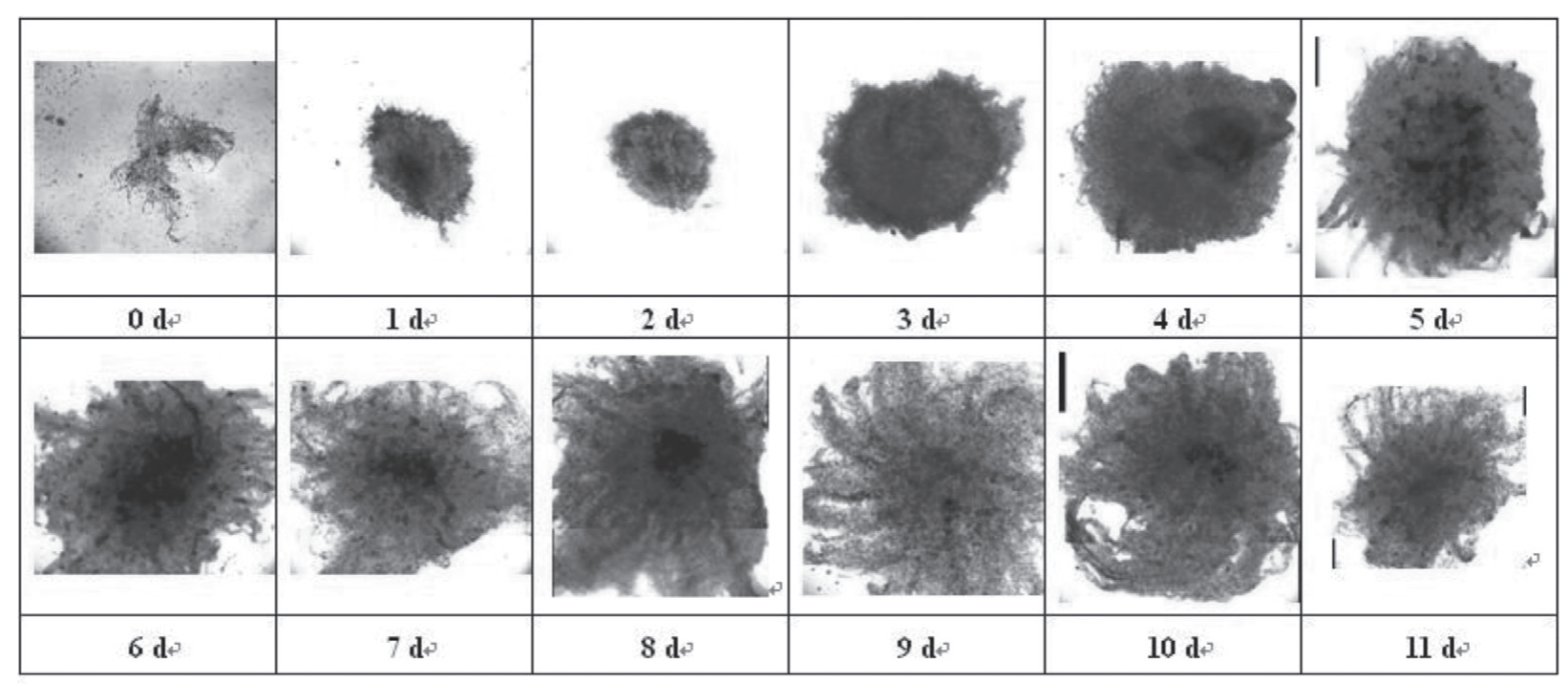

Fig. 3 - The morphological changes in P. geesteranus $5^{\#}$ in a stirred-tank fermenter. Representative images were taken at 40-fold magnification. 1-9d means fermentation period in day. 


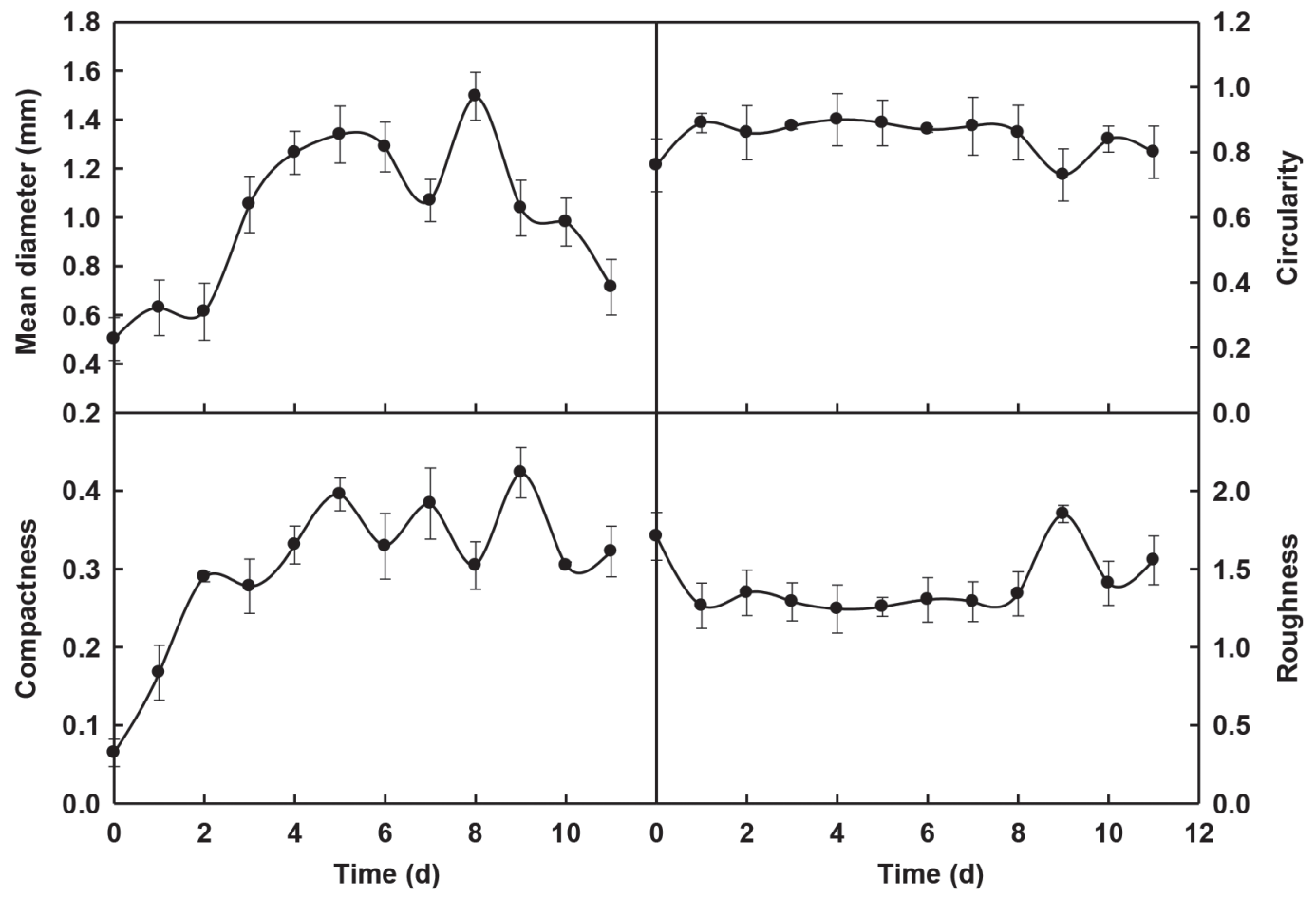

Fig. 4 - Mean diameter (A), circularity (B), compactness (C) and roughness (D) of P. geesteranus $5^{\#}$ pellets growing in a stirred-tank fermenter.

\section{CONCLUSION}

In conclusion, P. geesteranus $5^{\#}$ EPS was concluded to have hypolipidemic effects in STZ-induced diabetic mice. Moreover, the pellet formation and viscosity during the fermentation of $P$. geesteranus $5^{\#}$ were investigated in the STR. The mean diameter and broth viscosity were highly correlated with EPS production. Further comprehensive pharmacological and biochemical investigations are, however, need to elucidate the exact mechanism of hypolipidemic action of the $P$. geesteranus $5^{\#}$ EPS, and to analyze any active compounds.

\section{ACKNOWLEDGMENTS}

This work was financially supported by National Natural Science Foundation of China (No. 21376227).

\section{RESUMO}

Neste estudo, foi investigado o efeito hipolipidêmico de exopolissacarideos (EPS) do licor de fermentação de Pleurotus geesteranus $5^{\#}$ em condições de cultura ideais num reator tanque agitado de $5 \mathrm{~L}$. O efeito hipolipidêmico do polissacarídeo, investigado em camundongos com diabetes induzida por estreptozotocina, diminuiu a glicose plasmática, o colesterol total e as concentrações de triacilglicerois em 17,1\%, 18,8 \% e $12,0 \%$, respectivamente. Os resultados do presente estudo demonstram firmemente o potencial deste polissacarídeo para prevenir a hiperglicemia em animais experimentais. Sob condições de cultura ideais, as concentrações máximas de micélio e de EPS foram 22,63 g/L após 7 dias de cultivo e 11,09 g/L, após 10 dias, respectivamente. Além disso, os parâmetros morfológicos (ou seja, o diâmetro médio, a circularidade, a rugosidade e compacidade) dos aglomerados e a viscosidade do caldo foram caracterizados. Foi provado que a compacidade da morfologia do aglomerado $\left(\mathrm{R}^{2}=0,963, \mathrm{p}<0,01\right)$ foi significativamente e positivamente determinada pela biomassa micelial. Além disso, o diâmetro médio $\left(\mathrm{R}^{2}=93,3, \mathrm{p}<0,01\right)$ e a viscosidade do caldo $\left.R^{2}=0,950, p<0,01\right)$ foram significativamente $e$ positivamente determinados pelo conteúdo de EPS. 
Palavras-chave: exopolissacarídeos, Pleurotus geesteranus, fermentação, efeito hipolipemiante, morfologia.

\section{REFERENCES}

BAe JT, Sinha J, PARK JP, Song CH And Yun JW. 2000. Optimization of submerged culture conditions for exobiopolymer production by Paecilomyces japonica. J Microbiol Biotechnol 10: 482-487.

BenwahHoud M, Jouad H, Eddouks M And Lyoussi B. 2001. Hypoglycemic effect of Suaeda fruticosa in streptozotocininduced diabetic rats. J Ethnopharmacol 76: 35-38.

BOLKENTA Ş, YANARDAĞB R, TABAKOĞLU-OĞUZA A AND ÖZSOY-SAÇAN Ö. 2000. Effects of chard (beta vulgaris L. var cicla) extract on pancreatic B-cell in STZ-diabetic rats: a morphological and biochemical study. J Ethnopharmacol 73: 251-259.

CERri MO AND BADINO AC. 2012. Shear conditions in clavulanic acid production by Streptomyces clavuligerus in stirred tank and airlift bioreactors. Bioprocess Biosyst Eng 35: 977-984.

GRAY AM AND FLATT PR. 1998. Insulin-releasing and insulinlike activity of Agaricus campestris (mushroom). J Endocrinol 157: 259-266.

He PX, Geng LJ, MaO DB, Wang Z and Xu CP. 2013. Production, preliminary characterization and bioactivity of exopolysaccharides from Pleurotus geestranus $5^{\#}$. Preparative Biochemi Biotechnol 43: 1-15.

HENRY RJUM. 1974. Clinical Chemistry, $2^{\text {nd }}$ ed., Harper and Row Publishers, New York, p. 1440-1443.

Hwang HJ, KIm SW, Lim JM, JOO JH, KIM HO, KIM HM AND YUN JW. 2005. Hypoglycemic effect of crude exopolysaccharides produced by a medicinal mushroom Phellinus baumii in streptozotocin-induced diabetic rats. Life Sci 76: 3069-3080.

HWANG HS, LEE SH, BAEK YM, KIM SW, JEONG YK AND YUN JW. 2008. Production of extracellular polysaccharides by submerged mycelial culture of Laetiporus sulphureus var. miniatus and their insulinotropic properties. Appl Microbiol Biotechnol 78: 419-429.

HWANG HS AND YUN JW. 2010. Hypoglycemic effect of polysaccharides produced by submerged mycelial Culture of Laetiporus sulphureus on streptozotocin-induced Diabetic Rats. Biotechnol Bioprocess Eng 15: 173-181.
OKADA M, Matsui H, ITO Y AND Fujiwara A. 2001. Direct measurement of HDL cholesterol: Method eliminating apolipoprotein E-rich particles. J Clin Lab Anal 15: 223-229.

PARK JP, KIM SW, HWANG HJ AND YUN JW. 2001. Optimization of submerged culture conditions for the mycelial growth and exo-biopolymer production by Cordyceps militaris. Lett Appl Microbiol 33: 76-81.

PARK JP, KIM YM, KIM SW, HWANG HJ, CHO YJ, LEE YS, SONG CH AND YUN JW. 2002. Effect of agitation intensity on the exo-biopolymer production and mycelial morphology in Cordyceps militaris. Lett Appl Microbiol 34: 433-438.

Riscaldati E, Moresi M, FEDERICI F AND PERUCiOLi M. 2000. Effect of $\mathrm{pH}$ and stirring rate on itaconate production by Aspergillus terreus. J Biotechnol 83: 219-230.

SinHA J, BAE JT, PARK JP, KIM KH, SONG CH AND YUN JW. 2001. Changes in morphology of Paecilomyces japonica and their effect on broth rheology during production of exo-biopolymers. Appl Microbiol Biotechnol 56: 88-92.

SONG CH, JEON YJ, YANG BK, RA KS AND KIM HI. 1998. Anti-complementary activity of endopolymers produced from submerged mycelial culture of higher fungi with particular reference to Lentinus edodes. Biotechnol Lett 20: 741-744.

VAN HORN LV. 1996. Lipid metabolism and choices for persons with diabetes. In: Powers MA (Ed), Handbook of Diabetes Medical Nutrition Therapy. Gaithersburg, MD: Aspen Publishers Inc., p. 336-359.

WANG Q, Li H, Chen TT AND HAN JR. 2011. Yield, polysaccharides content and antioxidant properties of Pleurotus abalonus and Pleurotus geesteranus produced on asparagus straw as substrate. Scientia Horticulturae 134: 222-226.

YANG BK, JeONG SC, LeE HJ, SOHN DH AND SONG CH. 2006. Antidiabetic and hypolipidemic effects of Collybia confluens mycelia produced by submerged culture in streptozotocin-diabetic rats. Arch Pharm Res 29: 73-79.

YESILADA O, SIK S AND SAM M. 1998. Biodegradation of olive oil mill wastewater by Coriolus versicolor and Funalia trogii: effects of agitation, initial COD concentration, inoculum size and immobilization. World J Microbiol Biotechnol 14: 37-42.

ZHANG M, ZHU L, CUI SW, WANG Q, ZHOU T AND SHEN H. 2011. Fractionation, partial characterization and bioactivity of water-soluble polysaccharides and polysaccharideprotein complexes from Pleurotus geesteranus. Int J Biol Macromol 48: 5-12. 